\title{
W prześwitach światłocieni
}

\section{Aleksandra Kosicka-Pajewska}

\author{
ORCID: 0000-0001-7884-0948
}

Badacze - literaturoznawcy, teatrolodzy i miłośnicy twórczości Stanisława Ignacego Witkiewicza otrzymali interesującą monografię o artyście pióra Ewy Szkudlarek pt. Portrety cieni Witkacego. Jest to książka wyjątkowa, oryginalna, odkrywcza, wprowadzająca nową metodologię w humanistyce. Autorka zastosowała w niej nowe metody pisania w dyskursie naukowym przedstawiła wizualne i metaforyczne aspekty cieni. Monografia badaczki to otwarcie nowego spojrzenia na twórczość Witkacego. Spośród bogatej literatury witkiewiczowskiej dzieło Ewy Szkudlarek wyróżnia się tym, że obejmuje wszystkie dziedziny twórczości Witkacego, a przede wszystkim, że opisuje problematykę dotąd niedostrzeżoną przez badaczy. O życiu i twórczości Witkacego powstało wiele rozmaitych prac odnoszących się do różnych zagadnień, pisano o formach osobowości - o szaleństwie, obłędzie, rozpaczy, melancholii, ale nikt dotąd nie zauważył „smugi cienia” zarówno w światopoglądzie, jak i w dziełach artysty ${ }^{1}$. Cień jest tym czynnikiem, który łączy i różnicuje całą twórczość zakopiańskiego artysty. Wieloaspektowość cienia w ujęciach kulturowych, psychologicznych, psychoanalitycznych, egzystencjalnych i w dziełach sztuki spaja całą twórczość artysty. Jest to wielka wartość interpretacyjna i odkrywcza autorki. Monografia Portrety cieni Witkacego to dzieło, które wyraźnie wskazuje na wyjątkową wrażliwość badaczki, na kulturowe odniesienia do emocji, doświadczenia oraz analizy poetyki i estetyki. Na podkreślenie zasługuje również wieloaspektowość rozważań badaczki

${ }^{1}$ Janusz Degler, Witkacego portret wielokrotny: szkice i materiały do biografii (1918-1939) (Warszawa: Państwowy Instytut Wydawniczy, 2009), Anna Żakiewicz, „Jednolity świat wyobraźni. O wątkach literackich w malarskiej twórczości Witkacego" w Witkacy. Życie i twórczość. Materiały sesji poświęconej Stanisławowi Ignacemu Witkiewiczowi z okazji 55. rocznicy śmierci (Muzeum Pomorza Środkowego, Słupsk 16-18 września 1994), red. Janusz Degler (Wrocław: „Wiedza o Kulturze”, 1996), Lech Sokół, Witkacy i Strindberg: dalecy i bliscy (Wrocław: „Wiedza o Kulturze”, 1995) i inni. 
na problem cienia rozumianego jako środek wyrazu, na „idiom poetycki”, który jest podstawowym elementem świata przedstawionego w dziełach zakopiańskiego artysty. Cień, jak zauważa Ewa Szkudlarek, pełni funkcję metafory ludzkiej kondycji, jej kruchości i ostateczności². Szczególnie nowatorsko zaprezentowano i wydobyto szereg znaczeń „estetyki cienia” i usytuowano je na granicy pomiędzy estetyką światła a estetyką ciemności. Książkę poznańskiej badaczki możemy potraktować jako rekonstrukcję cienia istniejącego lub zanikającego dzięki zjawisku światła zawartego w obrazach literackich i malarskich Witkiewicza.

Ewa Szkudlarek refleksję cienia analizuje na gruncie rozmaitych gatunków literackich (powieść, dramat ), malarskich (portret, pejzaż) i działań artystycznych (obrazy teatralne, fotograficzne i filmowe). Jak sama pisze we wstępie: „to kolejna, innowacyjna próba przedstawienia twórczości wybitnego XX-wiecznego polskiego artysty”, a także podkreśla, że „dla wybranej problematyki istotny jest także kulturowo-artystyczny i metafizyczno-egzystencjalny wymiar cienia w omawianej twórczości” ${ }^{3}$. Przy tak szeroko zakreślonym temacie pracy na podkreślenie zasługuje jasna i przejrzysta kompozycja książki. Całość materiału podzielona została na trzy części: I. Obrazy cienia, II. Iluzje cienia, III. Projekcje cienia, a każda z tych części dalej na rozdziały ${ }^{4}$.

W pierwszej części autorka omawia problematykę cienia w malarstwie (portretowym i pejzażowym) oraz w fotografii zakopiańskiego artysty. Badaczka analizuje twórczość Witkiewicza, gdzie widoczna jest „estetyka mimetyczna”. Druga część książki poświęcona została kreacji postaci tworzonych przez artystę i funkcji cienia dopełniającego kondycję człowieka w prozie i dramatach oraz w fotografii. Bohaterowie Witkacego są „ocienieni” i współtworzą tajemniczy, metaforyczny wymiar Istnienia Poszczególnego. W ostatniej części - trzeciej zapoznajemy się z dokonaniami Witkiewicza w aspekcie archetypu cienia Carla Gustava Junga. W tej części najpełniej widoczny jest autokreacyjny wymiar twórczości Witkacego na tle wątków biograficznych. Ewa Szkudlarek omawia różne odcienie ekspresji zakopiańskiego artysty zakorzenione w jego osobowości przez osobiste doświadczenia „smugi cienia” (m.in. przeżycia litewskie).

Witkacy w wypowiedziach estetycznych i teoretycznych nigdy nie wspominał o zjawisku cienia, a jednak cień jest obecny w jego artystycznych dziełach. Autorka zauważa, że w rozważaniach o psychologicznej teorii kolorów artysta mówi tylko o możliwości postrzegania zmysłem wzroku różnych barw. Dodaje także, że „Wizualizacja cienia jest wykorzystywana w malarskich, fotograficznych i literackich działaniach oraz wypowiedziach Witkacego. Dla artysty nie tylko forma, ale i kolory cienia mają istotne znaczenie. Bardzo interesujące w tym aspekcie są portrety kobiece, gdzie łatwo odczytać szczególną więź łączącą artystę z modelką. Cienie na portretach zostały wyrażone właśnie dzięki kolorom. Portrety ukazują złożoną skalę barwną: od tradycyjnych półtonów czerni do połyskliwej bieli (portret Marii Witkiewiczowej z 1918 roku,

\footnotetext{
${ }^{2}$ Ewa Szkudlarek, Portrety cieni Witkacego (Poznań: Wydawnictwo Naukowe UAM, 2018), 14.

${ }^{3}$ Szkudlarek, 22.

${ }^{4}$ Część I. Obrazy cienia - I. Portret malarski, II. Portret fotograficzny, III. Pejzaż malarski, IV. Pejzaż fotograficzny; część II. Iluzje cienia - V. Cienie postaci, VI. Cienie teatralne, VII. Cienie filmowe; część III. Projekcje cienia - VIII. Cień osobowości, IX. Barwy cienia, X. Transformacja cienia. Poszczególne części i rozdziały zapowiadają logiczną konstrukcję wywodu.

${ }^{5}$ Beata Popczyk-Szczęsna, recenzja książki „Portrety cieni Witkacego”, artPapier, http://artpapier.com/index.php ?page $=$ artykul\&wydanie $=380 \&$ artykul=7550 (dostęp: 30.03 .2021$)$.
} 
portret Edwardy Szmuglarowskiej z 1930 roku), żółcieni, czerwieni, fioletu, błękitu (portret Leny Iżyckiej z 1925 roku, portret Małgorzaty Wandy Żukotyńskiej z 1928 roku, portret Heleny Białynickiej-Biruli z 1929 roku”.

Wojciech Sztaba pisze tak: „Portrety to najczęściej rysunek kolorem, i tę wartość Witkacy szczególnie akcentuje. Portrety zbudowane są z „szybujących” kresek koloru, jedna nad drugą układających się w barwne warstwy. Znane już z pastelowych kompozycji jarzenie się barw zjawia się również, tym razem są to najczęściej świetliste linie, smugi koloru, jarzące się druciki””.

Uwagę szczególną zwraca analiza i wizualizacja cienia portretów malowanych w ramach tzw. „Firmy portretowej S.I. Witkiewicz” oraz portretów fotograficznych. Erudycja badaczki pozwala jej na umiejętne posługiwanie się wiedzą z zakresu malarstwa, historii sztuki, estetyki, literatury, dramatu, fotografii, psychologii. Stąd zwrócenie uwagi na „kolory cienia”, dla Witkacego nie tylko forma ma znaczenie, ale także cień. Przez owe „szybujące kreski” zakopiański artysta wydobywał z modela ludzką duszę. Sam Witkacy podzielił portrety na pięć typów w zależności od usytuowania na skali - od naturalizmu do Czystej Formy. Sposób malowania portretów przez Witkiewicza autorka nazwała „psychologią pędzla”, starał się bowiem uchwycić nie tylko fizyczne podobieństwo portretowanego, ale co ważniejsze - cechy psychologiczne. Wydobycie w portrecie fizis i psyche stawało się oryginalnym świadectwem inwencji artystycznej oraz wielkim talentem artysty. Ewa Szkudlarek, analizując portrety Witkacego - malowane i fotografowane - nie tylko zauważa charakterystyczne cechy obrazów, ale opisuje szczególne relacje między malarzem a modelem. Dobitnie podkreśla: „Każdy portret Witkacego to dokładnie przemyślane studium twarzy, podkreślające osobowość osoby portretowanej. Między artystą a modelem dochodzi do szczególnego kontaktu wzrokowego, który przyczynia się do wzajemnego odbicia cienia emanującego z oczu"8. Witkacy to nie tylko artysta, który odtwarzał jak w lustrzanym odbiciu modele, „aby zobaczyć, jak gęsta lub rozrzedzona pajęczyna cieni okala policzki, oczy, włosy malowanych postaci. Artysta energicznie i zdecydowanie kładzie grube kreski, zostawia między nimi prześwity, dzięki czemu twarze na portretach lub autoportretach wyglądają tak, jakby były smagane cieniem”. Ta gra światła i cienia jest głównym nośnikiem wizualnym, charakterystycznym środkiem wyrazu, jaki stosuje artysta. Jest to także ważny element kompozycji w powieściach i dramatach.

Badaczka analizuje portrety malowane i fotografowane, sprawnie posługując się wiedzą z dziedziny technik robienia zdjęć (możemy prześledzić historię technik fotografowania), historii sztuki, psychologii, którą umiejętnie wplata w analizę własną na temat twórczości Witkacego. Wyzyskuje także wiedzę teoretyczną artysty, by podkreślić, jak wielką rolę w rozważaniach Witkacego o świecie odgrywał cien.

Szczególną uwagę warto zwrócić na znakomitą interpretację fotografii wizerunku narzeczonej Witkiewicza, zwłaszcza w perspektywie późniejszych tragicznych wydarzeń. Ewa Szkud-

\footnotetext{
${ }^{6}$ Szkudlarek, Portrety cieni Witkacego, 15.

${ }^{7}$ Wojciech Sztaba, Gra ze sztuką. O twórczości Stanisława Ignacego Witkiewicza (Kraków: Wydawnictwo Literackie, 1982), 116

${ }^{8}$ Szkudlarek, Portrety cieni Witkacego, 46.

${ }^{9}$ Szkudlarek, 14.
} 
larek w portretach fotograficznych Jadwigi Janczewskiej dostrzegła „formę artystycznego przeczucia”. Witkacy widzi narzeczoną jako „wieczną narzeczoną w krainie cieni” ${ }^{10}$. Portrety, na których uwiecznił Witkacy twarz swojej wybranki, nie są wiernym odbiciem kobiety. Artysta w portretach fotograficznych stosuje pewnego rodzaju grę różnymi środkami postrzegania. Wrażliwość Witkacego, a także umiejętność operowania światłem i cieniem przyniosła efekt końcowy odzwierciedlający dramatyczność, nie tylko kobiety, ale i relacji między narzeczonymi.

Zakopiański artysta wykonał wiele zdjęć Jadwigi Janczewskiej, ale dwa z nich zasługują na szczególną uwagę ze względu na interpretacje badaczki. To dwie fotografie z roku 1913, dwa odmienne ujęcia narzeczonej w kapeluszu z woalką. Oto opis pierwszego zdjęcia: „odwraca spojrzenie od aparatu fotograficznego, patrzy zamyślona w przestrzeń u dołu. Jej rozłożysty kapelusz rzuca wyraźny cień na wzorzystą ścianę. To chwilowe zastygnięcie postaci na fotografii przywodzi na myśl nieoczekiwane zejście do podziemia Hadesu pięknej Eurydyki... ${ }^{11}$. Drugie zdjęcie „eksponuje powiększone cienie rzęs. [...] A zatem rzęsy dziewczyny i koronkowy haft tworzą układ wijącej się nici...”12. Autorka przejawia umiejętność tworzenia wielokontekstowych i inspirujących oraz sugestywnych interpretacji. Dysponuje bogactwem skojarzeń i uruchamia wiele kontekstów, np. wiersz Staffa, Cień, elementy Erosa i Thanatosa, Orfeusza i Eurydyki czy dramat Orfeusz Anny Świrszczyńskiej.

Wyżyny interpretatorskie autorka monografii osiągnęła przy omawianiu autoportretów artysty, namalowanych „niespokojnymi, nerwowymi kreskami, wystającymi poza owal twarzy. Te kreski chwilami sterczą jak kolce lub druciana siatka. Witkacy w ten sposób zagęszcza mrok wokół własnej postaci, łapiąc ją niejako w sieć, pokazując, że skazana jest na poranienie. Przypomina także o tym, że jego własna osoba jest skazana na zranienie i znajduje się w sytuacji bez wyjścia. Artysta umieszcza siebie w przestrzeni wrogiej i niebezpiecznej i do pewnego stopnia klaustrofobicznej"13.

Bardzo interesujące jest wyeksponowanie cienia wywodzącego się z autobiografii, autokreacji i twórczości zakopiańskiego artysty. Życiu Witkacego towarzyszyła atmosfera tajemnicy i skandalu, którą sam kreował. Jego codzienność była kontynuacją stylu młodopolskich modernistów, dla których szokowanie stało się zarówno rozrywką, jak i wyróżnikiem siebie jako artysty. Życie Witkiewicza dało asumpt Ewie Szkudlarek do analizy cienia, odwołując się do współczesnej psychologii i psychiatrii. Cień przedstawia jako wyraz napięcia, metafizyczny lęk, który jest łącznikiem między światem zewnętrznym i wewnętrznym. Jest wizualizacją archetypu nieświadomych treści psychicznych ludzkiej natury.

W rozdziale Pejzaż malarski Ewa Szkudlarek podkreśla, że Witkacy, tak jak inni artyści awangardowi, motyw cienia stosował jako element symboliczny, element ekspresji. Badaczka pisze: „Pejzaże Witkacego nie są dla mnie tematem samym w sobie, ale kluczem do odczytania tych

\footnotetext{
${ }^{10}$ Szkudlarek, 61.

${ }^{11}$ Szkudlarek, 62.

${ }^{12}$ Szkudlarek, 63.

${ }^{13}$ Szkudlarek, 47.
} 
prac artysty, które w szerokim zakresie eksplorują pojęcie przestrzeni. [...] Dla Witkacego dzieło jest swego rodzaju medium, aktualizującym wobec siebie stale nowe treści"14.

Ewa Szkudlarek zwraca uwagę na niezauważalne wcześniej aspekty dzieł fotograficznych Witkacego, podkreśla refleksje artysty nad krajobrazem, które doprowadziły do „własnej filozofii pejzażu"15. Styl malowanych obrazów i technika opisów w twórczości literackiej łączy wspólny obraz pejzażu. Szczególnie widoczny jest w utworach prozatorskich, takich jak: 622 upadki Bunga, Pożegnanie jesieni, Nienasycenie, Jedyne wyjście. Opisy krajobrazu, podkreśla badaczka, precyzyjnie pokazują szczególną „wrażliwość pejzażową artysty” ${ }^{16}$. Połączenia pejzażu z cieniem tworzą zjawisko z pogranicza realności i metafizyki, które wzajemnie na siebie oddziałują i są w określonej zależności.

Autorka dostrzega refleksję filozoficzną i estetyczną pejzażu zakopiańskiego artysty. Pejzaż w twórczości Witkiewicza nawiązuje do tradycyjnego widzenia dzieła sztuki, ale odczytać należy także nowatorskie „idee estetyczne” ${ }^{17}$. Badaczka odwołuje się do teoretycznych dawnych rozważań na temat cienia Leonarda da Vinci oraz koncepcji artystycznych impresjonistów i symbolistów. Artyści całej Europy w XX wieku zaczęli malować cienie inaczej. Tę inność badaczka widzi także w twórczości Witkacego, widzi ją jako istnienie cienia wewnętrznego i zewnętrznego.

W części drugiej książki Ewa Szkudlarek zawarła rozważania o cieniu jako śladzie i poddała problem ten dogłębnej analizie i interpretacji. Autorka w tym celu rozgranicza „cień” i „ślad”, łączy jak zawsze wiele dyscyplin naukowych (psychologię, filozofię, estetykę, literaturoznawstwo, historię sztuki) Jedną z ważniejszych kategorii antropologii jest refleksja „śladu”. Ewa Szkudlarek prowadzi interpretacje pojęcia „cień” i „ślad” na przykładzie witkacowskich fotografii na śniegu. Autorka odwołuje się do François Soulages’a, który twierdzi, że „zdjęcie jest śladem"18, ale przyjmuje za Barbarą. Skargą koncepcję filozoficzną śladu: „pojęcie śladu wiąże się z przestrzenią i czasem. Ślad jest zawsze tu, w danym miejscu [...] Ślad odsyła do przeszłości, do tego, co było, ale już nie jest, przynajmniej tu i teraz. To znak fenomenu z przeszłości, czegoś, co się wydarzyło, minęło, pozostawiło jednak swoją pieczęć mniej lub bardziej wyraźną [...] służące za dowód istnienia tej lub innej kultury"19. Ślad, twierdzi autorka, ma naturę cienia, może być „stały lub ulotny, wyrazisty lub zamglony, kształtny lub nieforemny”"20. Ślady podobnie jak cienie są kształtowane przez naturę. Ewa Szkudlarek przywołuje teorie: Heideggera, Platona czy Levinasa, co pozwala odnieść się do egzystencjalnego rozumienia cienia człowieka jako jednostki ludzkiej. Obraz fotograficzny jako „ślad śladu” przypomina Platońską teorię malarską "cień cienia”. Autorka w swojej monografii nie przejmuje automatycznie teorii Platona, ale prowadzi własny dyskurs interpretacyjny. Uważa, że Witkiewicz zarówno w fotografii czy malowanym obrazie nigdy nie osiągnie prawdy i „pełnego poznania”, zadowo-

\footnotetext{
${ }^{14}$ Szkudlarek, 78 .

${ }^{15}$ Szkudlarek, 80.

${ }^{16}$ Szkudlarek.

${ }^{17}$ Szkudlarek, 81.

${ }^{18}$ Szkudlarek, 138.

${ }^{19}$ Szkudlarek.

${ }^{20}$ Szkudlarek, 139.
} 
lić się może wyłącznie „cieniem świadomości, których odwzorowanie nie jest prawdą, ale tylko złudzeniem"21.

Przedstawione przez badaczkę fotografie ukazują różne formy Istnień Poszczególnych. Witkiewiczowskie pojęcie Istnienia Poszczególnego posłużyło autorce do reinterpretacji cienia jako zjawiska dopełniającego wizerunek człowieka ${ }^{22}$. Kreacje różnych postaci artysty: w literaturze, dramacie, fotografii dopełnia cień, który współtworzy tajemniczy wizerunek człowieka. Ów cień jest równorzędny z opisem bohatera, układem ciała, wyrazem twarzy, wypełnia duchowy wymiar Istnienia Poszczególnego. Autorka rozprawy Istnienie Poszczególne rozważa w kategorii egzystencjalnej o metafizycznym wymiarze, pełne niepokoju, tak jak rozumie je artysta. Badaczka dokonuje reinterpretacji pojęcia Istnienia Poszczególnego. Cień analizuje w aspekcie definicji Carla Gustava Junga, chociaż nie zajmuje się psychoanalizą, lecz metaforą cienia jako formą poznania, która przedstawiona jest jako forma pojęciowa i artystyczna metafizycznym (w rozumieniu Witkiewicza) niepokojem. Metafora cienia w ujęciu badaczki dzieli się na pojęciową i poetycko-artystyczną. Autorka poddaje analizie pięć zasadniczych znaczeń metafory cienia, które się wzajemnie uzupełniają, a w interpretacjach stają się ważne. Cień wywodzi z twórczości i refleksji samego Witkiewicza bądź ze współczesnej psychologii i psychoterapii i stanowią one definicje uzupełniające lub spajają poszczególne ujęcia i analizy.

Problematykę cienia i śladu badaczka dostrzegła także w utworach dramatycznych: $W$ matym dworku, Kurce Wodnej, Pragmatystach. Gra światłem i cieniem to podstawowe zagadnienie przedstawień teatralnych. W utworach dramatycznych Witkacego cień pełni funkcję „estetyzmu sztuki wyobrażonej”. Jak pisze autorka: „galeria postaci w jego dramatach wzbogaciła teatr w metaforę obrazu i cienia"23. Bohaterowie sztuk zakopiańskiego artysty zostali wydobyci z beznadziejnej zbiorowości - samotni, bezsilni, i zostali „ubrani” światłem dla podkreślenia sensu istnienia, a ich cień stanowi istotę ludzkiej egzystencji, osobowość jednostki. Interpretacja postaci Mamalii z Pragmatystów i jej taniec przedstawiona została ciekawie i odkrywczo. Ewa Szkudlarek pisze: „Obserwując taniec Mamalii i dokonując analizy znaczeń imienia bohaterki, można szukać różnorodnych form cienia. W zależności od tego, jaką figurę prezentuje na scenie: bezwolną marionetkę, biedną kukłę czy tancerkę kabaretu, jej oświetlonemu ciału towarzyszy cień" ${ }^{24}$.

Inny przykład to bohaterowie z dramatu $W$ małym dworku, w którym widzimy „złożony proces przywracania tego, co zostało wyparte przez realizm; pozyskanie materii ma pozwolić na ponowne odkrycie jej oraz duchowego wymiaru cienia" ${ }^{25}$. Autorka bohaterów dramatów Witkacego przedstawiła jako „cienie istnienia” z udziałem cienia jako elementu własnej osobowości.

\footnotetext{
${ }^{21}$ Szkudlarek, 162.

${ }^{22}$ Pod koniec lat dwudziestych Witkacy stworzył podstawy własnego systemu filozoficznego opartego na ontologii, który nazwał monadyzmem biologicznym. W 1935 roku myśli te zawarł w traktacie: Stanisław Ignacy Witkiewicz, Pojęcia i twierdzenia implikowane przez pojęcie istnienia: 1917-1932 (Warszawa: Instytut Popierania Nauki, 1935).

${ }^{23}$ Szkudlarek, Portrety cieni Witkacego, 167.

${ }^{24}$ Szkudlarek, 178.

${ }^{25}$ Szkudlarek, 182.
} 
Trzecia część monografii omawia projekcje cienia. W tych rozdziałach badaczka wraca ponownie do problemu istnienia między światłem a mrokiem, czyli dwóch zagadnień egzystencjalnych - fizycznego i metafizycznego. Odwołuje się do koncepcji psychologicznych C.G. Junga, by dokonać analizy archetypu cienia. Cień „jest problemem moralnym, który rzuca wyzwanie całej ego-osobowości, albowiem nikt nie potrafi zrealizować cienia, nie rozwijając w poważnym stopniu stanowczości moralnej”"26. W twórczości Witkiewicza badaczka dostrzega dwa światy - fizyczny i metafizyczny, czyli istnienie między światłem, mrokiem i cieniem. Cień łączy się ze świadomością człowieka, z jego psychiką. Ewa Szkudlarek przytacza interesujący przykład autoportretu Witkacego z 1938 roku - Dr Jekkyl i Mr Hyde ${ }^{27}$. Portrety te pokazują dwoistość natury ludzkiej (cień otacza jedną część twarzy, tło natomiast jest jednolicie czarne).

Inspirujące są dwa ostatnie rozdziały: Barwy cienia i Transformacja cienia. Kolor, w tym wypadku, niebieski „tworzy metafizyczną atmosferę stanu zawieszenia na granicy między sferą ziemską (kres Istnienia Poszczególnego) i nieziemską (nieskończoność Istnienia Poszczególnego) ${ }^{28}$. Odczytanie wieloaspektowego rozumienia barwy niebieskiej i interpretacja dzieł Witkacego na tle przemian w malarstwie XIX i XX wieku oraz inspiracji twórczości Ojca artysty, pozwoliła badaczce dostrzec więcej niż inni. Ewa Szkudlarek omawia „odcienie błękitu - jasny błękit, ciemny błękit, jaskrawy i wyblakły błękit” we wszystkich dziedzinach twórczości Witkacego, po raz kolejny pokazała swoją obszerną wiedzę i zdolności interpretatorskie. Analizy wizualne łączy autorka z nauką o widzeniu, powołując się na dzieła Rudolfa Arnheima czy badania Newtona wyzyskane przez Goethego.

Kolor, światło i cień wyróżnia twórczość Witkiewicza jako symbolikę „gaszenia lampy”, „nocnego motyla”, „szarej ćmy”, „płonącej świecy”, „pięknego ognia”. Poprzez reminiscencje pokazuje autorka ludzką duszę, przywołując dzieła literackie, fotografie, dramaty oraz film.

Odkrywanie światła i cienia przez odbiór doznań wizualnych z aktu obserwacji świata czyni flâneur wartości estetycznej. Poszukiwanie światła przez Witkacego to dążenie do osiągnięcia równowagi życia, a cień i mrok są tym, co pochłaniało jego świat. „Wszystko, co zawiera się w figurze Witkacowskiego flâneura, zostaje sprowadzone do wędrującego spojrzenia poszukującego źródła światła”29.

Monografia Ewy Szkudlarek Portrety cieni Witkacego oddaje także wrażliwość i subtelność autorki na słowo. Książkę wypełniają rozmaite koncepcje teoretyczne, które dzięki umiejętności posługiwania się poetyckim językiem współtworzą sugestywne obrazy. Jednak nie tylko „przyjemności tekstu" może oczekiwać czytelnik. W publikacji pojawiają się rozmaite dzieła Witkacego, znakomicie dobrane ilustracje, które budują wizualną historię znikliwego cienia artysty.

\footnotetext{
${ }^{26}$ Carl Gustav Jung, Archetypy i symbole. Pisma wybrane, wybrał, przeł. i wstępem poprzedził Jerzy Prokopiuk (Warszawa: Czytelnik, 1993), 69.

${ }^{27}$ Portrety te namalowane zostały wedle regulaminu Firmy Portretowej po zażyciu kokainy, wypiciu piwa czy paleniu papierosa - typ E.

${ }^{28}$ Szkudlarek, Portrety cieni Witkacego, 259.

${ }^{29}$ Szkudlarek, 285.
} 


\section{Bibliografia}

Degler, Janusz. Witkacego portret wielokrotny: szkice i materialy do biografii (1918-1939).

Warszawa: Panst. Instytut Wydaw., 2016.

Jung, Carl G. Archetypy i symbole. Pisma wybrane. Przetłumaczone przez Jerzy Prokopiuk. Warszawa: Czytelnik, 1993.

Popczyk-Szczęsna, Beata. „Tropami cieni... (Ewa Szkudlarek: 'Portrety cieni Witkacego')". artPapier 380 (2019). http://artpapier.com/ index.php?page =artykul\&wydanie $=380 \&$ artyk ul=7550 (dostęp: 12.06.2021).

Sokół, Lech. Witkacy i Strindberg - dalecy i bliscy. Wrocław: Wiedza o Kulturze, 1995.

Szkudlarek, Ewa. Portrety cieni Witkacego. Poznań: Wydawnictwo Naukowe UAM, 2019.

Sztaba, Wojciech. Gra ze sztukq o twórczości Stanisława Ignacego Witkiewicza. Kraków: Wydawnictwo Literackie, 1982.

Żakiewicz, Anna. „Jednolity świat wyobraźni. O wątkach literackich w malarskiej twórczości Witkacego". W Witkacy - życie i twórczość: materiały sesji poświęconej Stanisławowi Ignacemu Witkiewiczowi z okazji 55. rocznicy śmierci, zredagowane przez Janusz Degler. Słupsk: Muzeum Pomorza Środkowego, 1994. 


\title{
SEOWA KLUCZOWE:
}

\author{
W I T K A C Y
}

\section{obrazy cienia}

\section{B A R W Y C I E N I A}

\author{
cienie postaci \\ iluzja cienia
}

P R O J E K C J E C I E N I A

\begin{abstract}
AbStrakT:
Książka Ewy Szkudlarek Portrety cieni Witkacego jest nowatorskim spojrzeniem na twórczość Stanisława Ignacego Witkiewicza. Autorka przedstawiła wizualne i metaforyczne aspekty cieni, poddając analizie wszystkie dziedziny twórczości artysty, dotąd niedostrzeżone przez innych badaczy. Cień jest tym czynnikiem, który łączy i różnicuje całą twórczość zakopiańskiego artysty. Wieloaspektowość cienia w ujęciu kulturowym, psychologicznym, psychoanalitycznym, egzystencjalnym spaja twórczość Witkacego. Cień pełni funkcję metafory ludzkiej kondycji, jej kruchości i ostateczności.
\end{abstract}




\title{
portret malarski
}

T R A N S F OR M A C J E C I E IA

portret fotograficzny

\section{cienie filmowe}

\author{
pejzai malarski
}

\section{PORTRET FOTOGRAFICZNY}

\section{NOTA O AUTORCE:}

Aleksandra Kosicka-Pajewska - prof. UAM dr hab. Zakładu Estetyki Literackiej Instytutu Filologii Polskiej i Klasycznej Uniwersytetu im. Adama Mickiewicza w Poznaniu, historyk. Autorka wielu artykułów interdyscyplinarnych z dziedziny kultury polskiej i historii oraz książek: Między Niemcami a Rosja. Koncepcje polityczne Adolfa Bocheńskiego (Poznań 1992), Zachowawcza myśl polityczna w Galicji w latach 1864-1914 (Poznań 2002), Kwintet warszawski. Szkic do portretu zbiorowego stołecznej inteligencji dwudziestego wieku (Poznań 2016), Stanisław Tarnowski. Szkic do portretu (Poznań 2019, współautorka).W przygotowaniu Władysław Sikorski 1939-1943. Historia polityczna. 